\title{
ANALISIS FAKTOR YANG BERHUBUNGAN DENGAN KEPATUHAN MENGGUNAKAN ALAT PELINDUNG DIRI
}

\author{
ANALYSIS OF FACTOR RELATED TO COMPLIANCE OF \\ USING PERSONAL PROTECTIVE EQUIPMENT
}

\author{
Kartika Dyah Sertiya Putri \\ Ikatan Ahli Kesehatan Masyarakat Indonesia (IAKMI), Surabaya, Jawa Timur \\ E-mail: kartikadyahsertiyaputri@yahoo.com
}

\begin{abstract}
Using PPE (personal protective equipment) is the last risk control to protect the workers from occupational safety and health hazards. Applying safety culture through compliance behavior of wearing PPE is important to do as the responsibility of the company to protect its workers from occupational safety and health hazards. The purpose of this research was to analyze factors which have correlation with compliance of wearing PPE in aluminum sulfate unit production PT. Liku Telaga Gresik. This research was analytical observational with a cross sectional design. Subject of this research was total population that consist of 114 workers. Data would be shown in a frequency distribution and cross tabulation afterwards analyzed using statistic chi square. The result of research showed that most of workers obeyed to wear PPE in workplace. Statistic analytical results showed that education $(p=0.005 ; r=0.336)$ and attitude to the policy $(p=0.045 ; r=0.233)$ are factors which has correlated with compliance of wearing PPE. Age $(p=1)$, time of work $(p=1)$, knowledge $(p=0.483)$, motivation $(p=1)$, personality $(p=0.464)$, training $(p=0.559)$, communication $(p=0.72)$ and availability of PPE $(p=0.652)$ have no correlation with compliance of wearing PPE.
\end{abstract}

Keywords: safety culture, behavior of wearing PPE, workers in aluminum sulfate unit production

\begin{abstract}
ABSTRAK
Penggunaan APD (alat pelindung diri) merupakan pengendalian risiko terakhir untuk melindungi tenaga kerja dari bahaya keselamatan dan kesehatan kerja. Menerapkan kepatuhan menggunakan APD penting dilakukan sebagai tanggung jawab perusahaan untuk melindungi tenaga kerja dari bahaya keselamatan kerja dan kesehatan. Tujuan penelitian ini adalah menganalisis faktor yang berhubungan dengan kepatuhan menggunakan APD di unit produksi alumunium sulfat PT. Liku Telaga Gresik. Penelitian ini bersifat observasional analitik, dengan desain cross sectional. Subyek penelitian ini adalah total populasi yaitu 114 tenaga kerja. Data yang tersedia disajikan dalam bentuk distribusi frekuensi dan tabulasi silang kemudian dianalisis secara statistik chi square. Hasil penelitian menunjukkan bahwa sebagian besar tenaga kerja patuh menggunakan APD di tempat kerja. Hasil analisis statistik menunjukkan bahwa pendidikan $(p=0,005 ; r=0,336)$ dan sikap terhadap kebijakan $(\mathrm{p}=0,045 ; \mathrm{r}=0,233)$ sebagai faktor yang berhubungan signifikan dengan kepatuhan menggunakan APD dan memiliki kuat hubungan rendah. Umur $(p=1)$, masa kerja $(p=1)$, pengetahuan $(p=0,483)$, motivasi $(p=1)$, kepribadian $(p=0,464)$, pelatihan $(p=0,559)$, komunikasi $(p=0,72)$, dan ketersediaan APD $(p=0,652)$ tidak berhubungan dengan kepatuhan menggunakan APD.
\end{abstract}

Kata kunci: budaya keselamatan, perilaku penggunaan APD, pekerja unit produksi alumunium sulfat

\section{PENDAHULUAN}

Sebagai negara yang memiliki potensi alam besar, Indonesia berusaha memanfaatkan kekayaan alam tersebut dengan mengembangkan sektor industri. Berkembangnya sektor industri seringkali menimbulkan kecelakaan kerja yang merugikan tenaga kerja, perusahaan bahkan negara. Menurut Jamsostek yang dikutip oleh Ramli (2009), pada tahun 2007 tercatat 65.474 kecelakaan mengakibatkan 1451 orang meninggal, 5.326 orang cacat tetap dan 58.679 orang cedera.

Melihat besarnya angka kecelakaan kerja tersebut maka harus diselenggarakan pengendalian risiko berupa eliminasi, substitusi, teknik, administratif dan penggunaan APD. Berbagai upaya untuk mencegah kecelakaan kerja dan melindungi tenaga kerja dengan penggunaan APD namun masih seringkali ditemukan tenaga kerja yang tidak patuh 
dalam menggunakan APD. Menurut Sari (2012) menyebutkan dalam penelitiannya bahwa $26,3 \%$ tenaga kerja yang jarang menggunakan APD pernah mengalami kecelakaan kerja saat bekerja. Hal ini berarti kepatuhan dalam menggunakan APD juga memiliki hubungan untuk terjadinya kecelakaan kerja.

Banyak faktor yang menjadi penyebab tenaga kerja tidak patuh menggunakan APD meskipun perusahaan telah menyediakan APD dan menerapkan peraturan yang mewajibkan tenaga kerja menggunakan APD. Hal ini berarti masih ada yang perlu diteliti lebih lanjut terkait faktor yang mungkin dapat menyebabkan tenaga kerja patuh dalam menggunakan APD. Risiko terjadinya kecelakaan kerja dan penyakit akibat kerja yang mungkin terjadi karena pekerjaan membuat perusahaan tidak cukup hanya menyediakan APD dan mewajibkan tenaga kerja menggunakan APD ketika bekerja. Perusahaan juga harus menciptakan kepatuhan tenaga kerja untuk menggunakan APD. Tahap paling dasar untuk menumbuhkan kesadaran tenaga kerja supaya patuh menggunakan APD yaitu dengan pembentukan budaya keselamatan menggunakan APD (Reason, 2007).

Pada teori Geller (2001) mengungkapkan bahwa untuk membentuk budaya selamat terdapat tiga komponen yang saling berhubungan satu sama lain dan harus dicapai yaitu people (orang), behavior (perilaku), dan environment (lingkungan) yang disebut dengan safety triad. Komponen person terdapat beberapa faktor yaitu pengetahuan, kemampuan, keterampilan, kepandaian, motivasi dan kepribadian tenaga kerja. Faktor pada komponen behavior yaitu persetujuan, pelatihan, pengenalan, komunikasi, dan kepedulian yang aktif. Faktor pada komponen environment adalah peralatan dan perlengkapan, mesin, rumah tangga, suhu, teknik, standar dan prosedur operasional.

Menurut Geller (2001) pada teori safety triad, kepatuhan (compliance) merupakan salah satu faktor pada komponen behavior yang dipengaruhi oleh interaksi faktor pada komponen person dan environment. Penelitian tentang kepatuhan menggunakan APD terdahulu telah meneliti faktor yang menyebabkan kepatuhan menggunakan APD berdasarkan karakteristik tenaga kerja (Azis, 2010) dan teori perilaku Lawrence Green (Humau, 2012). Melalui penelitian ini, perlu dibuktikan beberapa faktor yang berhubungan dengan kepatuhan menggunakan APD melalui konsep safety triad sehingga menjadi rekomendasi perusahaan untuk menciptakan perilaku patuh menggunakan APD dari segi budaya.

\section{METODE}

Penelitian ini merupakan jenis penelitian observasional karena melakukan pengamatan tanpa memberikan perlakuan terhadap objek penelitian. Penelitian ini termasuk jenis penelitian analisis data karena menganalisis hubungan variabel tergantung dan variabel bebas. Penelitian ini menggunakan rancang bangun cross sectional karena pengamatan dilakukan pada suatu atau periode tertentu (Notoatmodjo, 2002). Populasi penelitian di unit produksi alumunium sulfat PT. Liku Telaga adalah 114 tenaga kerja.

Variabel dependen yang diteliti adalah kepatuhan tenaga kerja dalam menggunakan APD. Variabel independen yang diteliti pada penelitian ini adalah umur, masa kerja, pendidikan, pengetahuan, motivasi, kepribadian, pelatihan komunikasi, ketersediaan APD dan sikap terhadap kebijakan APD). Data diperoleh melalui kuesioner dan check list kemudian dianalisis menggunakan statistik chi square. Variabel independen yang memiliki hubungan signifikan dengan variabel dependen diuji kuat hubungan melalui analisis statistik koefisien kontingensi. Hasil analisis akan dikaitkan dengan teori yang ada dan hasil observasi melalui wawancara mendalam.

\section{HASIL}

\section{Karakteristik Responden}

Karakteristik responden meliputi umur, masa kerja dan pendidikan. Mayoritas tenaga kerja tergolong berusia muda yaitu $\leq 36$ tahun $(77 \%)$, memiliki masa kerja tergolong belum lama yaitu $\leq 13$ tahun (92\%) dan tamat SMA (95\%). Pada tabel 1 dapat diketahui bahwa variabel umur dan masa kerja tidak memiliki hubungan yang signifikan dengan kepatuhan tenaga kerja menggunakan APD di unit produksi alumunium sulfat PT. Liku Telaga karena memiliki nilai signifikan $<0,05$.

Tabel 1 juga menunjukkan bahwa variabel pendidikan berhubungan signifikan dengan kepatuhan menggunakan APD karena memiliki nilai signifikan $0,005<0,05$. Variabel pendidikan memiliki kuat hubungan yang rendah yaitu nilai koefisien kontingensi 0,336 . Tenaga kerja yang tamat SMA akan lebih patuh untuk menggunakan APD daripada yang tidak tamat SMA. 
Tabel 1. Hubungan Variabel Bebas dan Variabel Tergantung

\begin{tabular}{lccc}
\hline Variabel bebas & Nilai p & Nilai r & $\begin{array}{c}\text { Kuat } \\
\text { Hubungan }\end{array}$ \\
\hline Umur & $1>\alpha$ & - & - \\
Masa Kerja & $1>\alpha$ & - & - \\
Pendidikan & $0,05<\alpha$ & 0,336 & Rendah \\
Pengetahuan & $0,483>\alpha$ & - & - \\
Motivasi & $1>\alpha$ & - & - \\
Kepribadian & $0,464>\alpha$ & - & - \\
Pelatihan & $0,559>\alpha$ & - & - \\
Komunikasi & $0,720>\alpha$ & - & - \\
Ketersediaan & $0,611>\alpha$ & - & - \\
Sikap terhadap & $0,045<\alpha$ & 0,233 & Rendah \\
Kebijakan & & & \\
\hline
\end{tabular}

Keterangan: $\alpha=0,05$

\section{Komponen Person}

Komponen person meliputi pengetahuan, motivasi dan kepribadian. Sebagian besar tenaga kerja memiliki pengetahuan baik $(87,5 \%)$, motivasi baik $(96,6 \%)$ dan kepribadian tipe B $(61,4 \%)$. Variabel pengetahuan, motivasi dan kepribadian tidak memiliki hubungan yang signifikan dengan kepatuhan tenaga kerja menggunakan APD di unit produksi alumunium sulfat PT. Liku Telaga. Tabel 1 menunjukkan bahwa variabel pengetahuan, motivasi dan kepribadian memiliki nilai signifikan $<0,05$.

\section{Komponen Behavior}

Komponen behavior meliputi pelatihan dan komunikasi. Sebagian besar tenaga kerja pernah mendapatkan pelatihan menggunakan APD $(79,5 \%)$ dan memiliki komunikasi baik $(87,5 \%)$. Tabel 1 menunjukkan bahwa variabel pelatihan dan komunikasi tidak memiliki hubungan yang signifikan dengan kepatuhan tenaga kerja menggunakan APD di unit produksi alumunium sulfat PT. Liku Telaga. Variabel pelatihan dan komunikasi memiliki nilai signifikan $<0,05$.

\section{Komponen Environment}

Komponen environment meliputi ketersediaan APD dan sikap terhadap kebijakan tentang APD. Sebagian besar APD yang dimiliki tenaga kerja dalam kondisi lengkap dan baik $(94,3 \%)$ dan tenaga kerja memiliki sikap yang baik terhadap kebijakan tentang APD (93,2\%). Tabel 1 menunjukkan bahwa variabel ketersediaan APD tidak memiliki hubungan yang signifikan dengan kepatuhan tenaga kerja dalam menggunakan APD di unit produksi aluminum sulfat PT. Liku Telaga karena memiliki nilai signifikan $<0,05$.

Tabel 1 menunjukkan bahwa variabel sikap terhadap kebijakan tentang APD memiliki hubungan yang signifikan dengan kepatuhan menggunakan APD di unit produksi aluminium sulfat PT. Liku Telaga. Sikap terhadap kebijakan memiliki nilai signifikan $p=0,045$ dan memiliki kuat hubungan nilai koefisien kontingensi sebesar 0,233. Sikap terhadap kebijakan memiliki kuat hubungan yang rendah dengan kepatuhan menggunakan APD. Tenaga kerja yang memiliki sikap baik terhadap kebijakan tentang APD lebih patuh menggunakan APD daripada yang memiliki sikap kurang baik.

\section{Kepatuhan}

Sebagian besar tenaga kerja di unit produksi alumunium sulfat patuh menggunakan APD dengan lengkap dan benar (78\%).

\section{PEMBAHASAN}

\section{Hubungan Umur dengan Kepatuhan Menggunakan APD}

Menurut Notoatmodjo (2012), perilaku merupakan perpaduan antara faktor internal yang terdiri dari kecerdasan, persepsi, motivasi, minat dan emosi dan faktor eksternal yang terdiri dari objek kelompok dan hasil kebudayaan. Perilaku juga bergantung pada karakteristik atau faktor lain dari tenaga kerja itu sendiri. Salah satu karakteristik dari tenaga kerja adalah faktor umur yang memengaruhi perilaku patuh menggunakan APD.

Penelitian yang dilakukan pada unit produksi alumunium sulfat di PT. Liku Telaga tidak dapat membuktikan hipotesis ini. Penelitian tersebut menyatakan bahwa tidak ada hubungan bermakna antara umur dan kepatuhan tenaga kerja dalam menggunakan APD. Penelitian ini sejalan dengan penelitian yang dilakukan oleh Ahyar (2001) yang menyatakan bahwa tidak ada hubungan antara umur dengan kepatuhan menggunakan APD hidung dan mulut.

Pada kenyataannya berdasarkan penelitian yang telah dilakukan di unit produksi Alumunium sulfat PT. Liku Telaga sesuai dengan tabel 1 , baik tenaga kerja yang memiliki usia muda atau tua memiliki persentase kepatuhan yang sama tinggi. Hal ini 
berarti umur memang bukan menjadi faktor yang berhubungan dengan kepatuhan menggunakan APD.

\section{Hubungan Masa Kerja dengan Kepatuhan Menggunakan APD}

Menurut Notoatmodjo (2012), masa kerja merupakan salah satu faktor pada karakteristik tenaga kerja yang membentuk perilaku. Semakin lama masa kerja tenaga kerja akan membuat tenaga kerja lebih mengenal kondisi lingkungan tempat kerja.

Jika tenaga kerja telah mengenal kondisi lingkungan tempat kerja dan bahaya pekerjaannya maka tenaga kerja akan patuh menggunakan APD. Hipotesis ini tidak dapat dibuktikan pada penelitian di unit produksi Alumunium sulfat PT. Liku Telaga yang menyatakan bahwa tidak ada hubungan kepatuhan menggunakan APD. Penelitian ini sejalan dengan penelitian yang dilakukan oleh Ahyar (2001) yang menyatakan bahwa tidak ada hubungan yang signifikan antara masa kerja dengan kepatuhan menggunakan APD hidung dan mulut. Buktinya, tenaga kerja yang belum lama bekerja di perusahaan maupun yang telah lama bekerja di perusahaan memiliki persentase kepatuhan yang hampir sama besar.

\section{Hubungan Pendidikan dengan Kepatuhan Menggunakan APD}

Berdasarkan observasi, masih terdapat tenaga kerja yang tidak tamat SMA. Hasil analisis statistik bivariat seperti yang dijelaskan pada tabel 1, pendidikan memiliki hubungan yang signifikan dengan kepatuhan tenaga kerja dalam menggunakan APD di unit produksi alumunium sulfat PT. Liku Telaga. Nilai koefisien kontingensi kuat hubungan pendidikan dan kepatuhan menggunakan APD adalah rendah.

Menurut Notoatmodjo (2012), pendidikan merupakan salah satu faktor pada karakteristik tenaga kerja yang akan memengaruhi perilaku. Pendidikan juga akan memengaruhi tenaga kerja dalam upaya mencegah penyakit dan meningkatkan kemampuan memelihara kesehatan. Meskipun pendidikan memiliki kuat hubungan yang rendah dengan kepatuhan menggunakan APD namun pendidikan tetap menjadi faktor yang mendukung tenaga kerja patuh menggunakan APD. Patuh menggunakan APD berarti tenaga kerja berupaya memelihara kesehatannya dan melindungi diri dari bahaya keselamatan dan kesehatan kerja.
Hal ini juga sejalan dengan penelitian Humau (2012) yang menyatakan bahwa terdapat hubungan antara tingkat pendidikan tenaga kerja dengan kepatuhan menggunakan APD. Penelitian yang dilakukan oleh Jannah (2009) juga menyatakan hal yang sama tentang kuat hubungan pendidikan dengan kepatuhan menggunakan APD yang rendah. Rendahnya kuat hubungan pendidikan dengan kepatuhan menggunakan APD dikarenakan tingkat pendidikan tidak berpengaruh langsung terhadap penggunaan APD tetapi hanya memengaruhi pola pikir tenaga kerja. Cara berpikir tenaga kerja yang dimaksud adalah tenaga kerja memahami bahaya yang ada di tempat kerja dan cara mengatasinya misalnya dengan menggunakan APD.

Berdasarkan tabel 1 yang menjelaskan hasil penelitian di unit produksi alumunium sulfat PT. Liku Telaga, pendidikan merupakan faktor yang memiliki hubungan dengan kepatuhan menggunakan APD. Hasil penelitian ini dapat dijadikan rekomendasi bagi perusahaan untuk merekrut tenaga kerja yang memiliki pendidikan tinggi yaitu tamat SMA. Tenaga kerja yang tamat SMA akan lebih mudah diarahkan untuk patuh menggunakan APD daripada tenaga kerja yang tidak tamat SMA.

\section{Hubungan Pengetahuan dengan Kepatuhan Menggunakan APD}

Pengetahuan merupakan salah satu faktor dalam komponen person pada teori safety triad yang akan memengaruhi kepatuhan (Geller, 2001). Teori safety triad ini berarti menjelaskan bahwa pengetahuan seharusnya memiliki hubungan yang signifikan dengan kepatuhan tenaga kerja dalam menggunakan APD. Berdasarkan hasil penelitian pada tabel 1 yang dilakukan pada unit produksi alumunium sulfat PT. Liku Telaga tidak dapat membuktikan hipotesis bahwa terdapat hubungan yang signifikan antara pengetahuan dengan kepatuhan menggunakan APD.

Tenaga kerja yang berpengetahuan baik maupun kurang memiliki persentase yang hampir sama besar untuk patuh menggunakan APD. Hasil penelitian ini didukung oleh penelitian Hastanti (2004) yang menyatakan bahwa tidak ada hubungan antara pengetahuan dengan pemakaian APD. Hasil penelitian Hastanti (2004) menyatakan bahwa pengetahuan yang baik maupun kurang tidak selalu menyebabkan kedisiplinan untuk patuh menggunakan APD saat bekerja.

Sebagian besar tenaga kerja memang telah memiliki pengetahuan yang baik namun pada 
kenyataannya pengetahuan baik tidak menjamin tenaga kerja patuh menggunakan APD. Tidak adanya jaminan bahwa tenaga kerja yang memiliki pengetahuan tinggi akan patuh menggunakan APD karena pengetahuan yang dimiliki tenaga kerja hanya sampai pada pengetahuan tingkatan pertama. Menurut Notoatmodjo (2003), pengetahuan tingkat pertama merupakan pengetahuan yang sekedar mengingat informasi yang diterima. Pengetahuan tenaga kerja yang tinggi tentang APD karena tenaga kerja hanya mengingat informasi tentang APD namun belum mencapai tingkat memahami dan mengaplikasikan penggunaan APD.

\section{Hubungan Motivasi dengan Kepatuhan Menggunakan APD}

Menurut Budiono (2003), penggunaan APD merupakan salah satu bentuk dari perilaku aman. Kepatuhan merupakan salah satu faktor pada komponen behavior dalam teori safety triad (Geller, 2001). Menurut Schein (2002) dalam Leka dan Houdmont (2010), perilaku patuh adalah contoh dari artefak yang merupakan lapisan terluar suatu budaya. Interaksi antar komponen pada teori safety triad menjelaskan bahwa motivasi dalam komponen person akan memengaruhi kepatuhan pada komponen behavior.

Hasil penelitian seperti pada tabel 1 yang dilakukan pada unit produksi alumunium sulfat PT. Liku Telaga tidak dapat membuktikan hipotesis ada hubungan antara motivasi dengan kepatuhan menggunakan APD. Berdasarkan analisis data seperti pada tabel 1, motivasi tidak memiliki hubungan yang signifikan dengan kepatuhan menggunakan APD. Hasil penelitian lain yang dilakukan oleh Retnani (2013) juga mendukung tidak terbuktinya hubungan motivasi dengan kepatuhan menggunakan APD yang merupakan salah satu bentuk dari perilaku aman.

McSween (2003) mengemukakan bahwa motivasi merupakan salah satu faktor dari activator yang akan memengaruhi kepatuhan menggunakan APD namun tidak menjamin suatu perilaku kepatuhan menggunakan APD akan terbentuk. Penelitian yang dilakukan di unit produksi alumunium sulfat PT. Liku Telaga yang menyatakan tidak ada hubungan antara motivasi dengan kepatuhan menggunakan APD karena motivasi bukan menjadi faktor yang berhubungan dengan kepatuhan tenaga kerja. Berdasarkan observasi, tenaga kerja yang memiliki motivasi baik maupun kurang tetap memperoleh persentase tinggi untuk patuh menggunakan APD. Meskipun motivasi menggunakan APD merupakan activator yang membentuk perilaku patuh menggunakan APD namun motivasi ini tidak cukup memberikan pengaruh untuk menghasilkan perilaku patuh menggunakan APD.

\section{Hubungan Kepribadian dengan Kepatuhan Menggunakan APD}

Geller (2001) mengemukakan dalam teori safety triad yang membentuk budaya keselamatan, terdapat komponen yang berkaitan satu sama lain yaitu komponen person, behavior dan environment. Kepribadian merupakan salah satu faktor dalam komponen person sehingga akan berkaitan dengan perilaku kepatuhan menggunakan APD. Kepribadian A akan cenderung selalu bergerak dengan cepat, merasa tidak sabar dan tidak suka waktu bersantai sedangkan kepribadian B lebih suka bersantai, berorientasi memperoleh kegembiraan dan tidak suka berkompetisi.

Penelitian yang dilakukan di unit produksi alumunium sulfat tidak dapat membuktikan hipotesis ini karena dari hasil observasi menyatakan bahwa tidak ada hubungan yang signifikan antara tipe kepribadian dengan kepatuhan menggunakan APD. Berdasarkan observasi seperti yang ditunjukkan pada tabel 1, meskipun tidak ada hubungan yang signifikan namun tipe kepribadian B memiliki persentase lebih besar untuk patuh menggunakan APD daripada tipe kepribadian A. Persentase tipe kepribadian $\mathrm{B}$ yang lebih besar daripada tipe kepribadian A menunjukkan bahwa tipe kepribadian B yang memiliki sifat lebih santai akan lebih sabar memeriksa kelengkapan APD sebelum bekerja sehingga kepribadian B akan lebih lengkap dan benar dalam menggunakan APD.

\section{Hubungan Pelatihan dengan Kepatuhan Menggunakan APD}

Menurut Atmodiwirio (2002) menyatakan bahwa pelatihan merupakan kegiatan yang didesain untuk membantu tenaga kerja memperoleh pengetahuan, keterampilan dan meningkatkan sikap, perilaku yang dibutuhkan untuk melaksanakan pekerjaan dengan baik. Hal ini berarti pelatihan seharusnya membuat tenaga kerja berperilaku sesuai dengan kebijakan penggunaan APD karena pelatihan merupakan salah satu bentuk pembinaan yang dapat diupayakan untuk membuat tenaga kerja patuh menggunakan APD. 
Tabel 1 menunjukkan bahwa penelitian yang dilakukan pada unit produksi alumunium sulfat PT. Liku Telaga tidak dapat membuktikan hipotesis ini karena hasil penelitian tersebut menyatakan bahwa tidak ada hubungan yang signifikan antara pelatihan menggunakan APD dengan kepatuhan menggunakan APD. Hal ini mungkin karena desain metode pelatihan yang didapatkan tenaga kerja belum mampu membantu tenaga kerja memperoleh pengetahuan, keterampilan, sikap dan perilaku menggunakan APD. Hasil penelitian ini didukung oleh penelitian yang dilakukan oleh Wibowo (2010) yang menyatakan bahwa tidak ada hubungan bermakna antara pelatihan menggunakan APD dengan penggunaan APD. Hasil penelitian yang bertolak belakang dengan penelitian yang dilakukan di unit produksi alumunium sulfat PT. Liku Telaga adalah penelitian Rengganis (2012) menyatakan bahwa pelatihan K3 mempunyai pengaruh yang signifikan terhadap penggunaan APD. Namun pada pelatihan pada penelitian ini hanyalah pelatihan pemadaman kebakaran dan karena perusahaan belum pernah ada dilakukan pelatihan penggunaan APD.

Menurut Bisen dan Priya (2010), pelatihan adalah suatu proses pembelajaran yang memperdalam pengetahuan, kemampuan, peraturan atau mengubah perilaku untuk meningkatkan prestasi kerja. Berdasarkan definisi tersebut, maka perusahaan harus memberikan pelatihan yang mampu memperdalam pengetahuan tentang APD, kemampuan cara menggunakan APD, peraturan yang mengatur tentang APD, dan mengubah perilaku tidak patuh menjadi patuh menggunakan APD. Berdasarkan observasi melalui wawancara mendalam dengan sekretaris $\mathrm{P} 2 \mathrm{~K} 3$, perusahaan memberikan pelatihan menggunakan APD ketika briefing tiap unit produksi setiap hari Senin atau Rabu oleh sekretaris P2K3 dan supervisor. Hal ini bertujuan agar tenaga kerja mendapatkan informasi tentang APD dan berperilaku patuh menggunakan APD.

Meskipun tenaga kerja di unit produksi alumunium sulfat PT. Liku Telaga sebagian besar mengaku telah mendapatkan pelatihan menggunakan APD namun pelatihan ini belum mampu meningkatkan pengetahuan, keterampilan dan perilaku patuh untuk menggunakan APD. Tenaga kerja yang sudah pernah mendapatkan pelatihan APD namun tidak patuh menggunakan APD mungkin karena tenaga kerja tidak serius mengikuti pelatihan menggunakan APD yang diberikan. Desain metode pelatihan yang diberikan oleh perusahaan belum mampu mengubah perilaku seluruh tenaga kerja untuk patuh menggunakan APD. Tenaga kerja yang pernah mendapatkan pelatihan APD juga melanggar tidak menggunakan APD sehingga pelatihan yang diberikan perusahaan tersebut belum mampu mengubah perilaku menjadi patuh menggunakan APD.

Menurut Noe (2002) dalam Yuwono (2005), pelatihan adalah suatu kegiatan yang direncanakan oleh perusahaan untuk memfasilitasi proses belajar tenaga kerja agar dapat mencapai kompetensi dalam pekerjaannya. Pelatihan yang diberikan oleh perusahaan melalui briefing unit produksi tidak sesuai dengan definisi pelatihan tersebut. Pelatihan yang diberikan seharusnya memang diadakan khusus untuk memfasilitasi tenaga kerja agar berkompetensi dalam menggunakan APD. Hal ini dapat menyebabkan tidak berhasilnya pembuktian hipotesis bahwa pelatihan memiliki hubungan yang signifikan dengan kepatuhan menggunakan APD. Oleh karena itu perusahaan perlu mengadakan pelatihan khusus untuk meningkatkan pengetahuan, kemampuan, keterampilan, kesadaran dan kepatuhan menggunakan APD. Pelatihan khusus menggunakan APD tidak disamakan dengan penjelasan informasi mengenai APD pada briefing.

\section{Hubungan Komunikasi dengan Kepatuhan Menggunakan APD}

Komunikasi merupakan salah satu faktor dalam komponen behavior yang berkaitan dengan kepatuhan pada teori safety triad (Geller, 2001). Berdasarkan teori safety triad tersebut dapat diambil kesimpulan bahwa komunikasi seharusnya memiliki hubungan dengan perilaku kepatuhan menggunakan APD.

Tabel 1 menunjukkan bahwa penelitian yang dilakukan di unit produksi alumunium sulfat PT. Liku Telaga tidak dapat membuktikan hipotesis ini karena hasil penelitian menyatakan bahwa tidak ada hubungan yang signifikan antara komunikasi dengan kepatuhan. Hasil penelitian ini didukung oleh penelitian Haqi (2013) yang menyatakan bahwa tidak ada pengaruh antara interaksi atau komunikasi antar tenaga kerja dengan terjadinya unsafe action. Hal ini berarti tenaga kerja yang memiliki komunikasi baik maupun kurang masih memiliki kemungkinan untuk tidak patuh menggunakan APD.

Tidak adanya hubungan antara komunikasi dengan kepatuhan menggunakan APD karena 
rangsangan yang diberikan sesama tenaga kerja maupun rangsangan dari atasan ke bawahan tidak mampu membuat tenaga kerja patuh menggunakan APD. Atasan atau rekan kerja yang mengingatkan mungkin juga sering tidak patuh menggunakan APD sehingga meskipun komunikasi baik namun tidak mampu membentuk perilaku patuh menggunakan APD. Komunikasi yang ada di unit produksi alumunium sulfat PT. Liku Telaga sebesar $87,5 \%$ tergolong baik namun dari $29 \%$ dari $87,5 \%$ tersebut masih tidak patuh menggunakan APD. Besarnya persentase yang tidak patuh tersebut mungkin menyebabkan komunikasi tidak memiliki hubungan yang signifikan dengan kepatuhan menggunakan APD. Berdasarkan observasi di unit produksi alumunium sulfat PT. Liku Telaga, tenaga kerja yang memiliki komunikasi tergolong baik ternyata masih tidak patuh menggunakan APD.

\section{Hubungan Ketersediaan APD dengan Kepatuhan Menggunakan APD}

Ketersediaan merupakan salah satu pada faktor enabling yang memengaruhi perilaku seseorang (Notoatmodjo, 2003). Tabel 1 menunjukkan bahwa hasil penelitian yang dilakukan di unit produksi alumunium sulfat PT. Liku Telaga menyatakan bahwa tidak ada hubungan yang signifikan antara ketersediaan APD dengan kepatuhan menggunakan APD. Hasil penelitian ini sejalan dengan penelitian yang dilakukan oleh Rengganis (2012) bahwa meskipun perusahaan telah menyediakan APD secara gratis namun tidak cukup membuat tenaga kerja sadar akan pentingnya APD saat bekerja. Hasil penelitian ini didukung oleh penelitian Zaendar (2009) bahwa tidak ada pengaruh antara ketersediaan APD dengan perilaku bekerja dengan selamat.

Berdasarkan observasi di lapangan, kenyataannya masih ada tenaga kerja yang mengeluh mengalami sesak napas karena debu alumunium sulfat pada proses grinding mill meskipun telah menggunakan APD. Gangguan pernapasan ini disebabkan oleh alat pelindung pernapasan tidak mampu melindungi tenaga kerja dari serbuk alumunium sulfat sehingga perlu dilakukan evaluasi penyediaan APD yang sesuai dengan bahaya pekerjaan di mesin grinding mill.

Berdasarkan observasi di lapangan, kenyataannya masih ada tenaga kerja yang mengeluh mengalami sesak napas karena debu alumunium sulfat pada proses grinding mill meskipun telah menggunakan APD. Gangguan pernapasan ini mungkin karena alat pelindung pernapasan tidak mampu melindungi tenaga kerja dari serbuk alumunium sulfat sehingga perlu dilakukan evaluasi penyediaan APD yang sesuai dengan bahaya pekerjaan di mesin grinding mill.

Berdasarkan observasi di lapangan, tenaga kerja menggunakan alat pelindung pernapasan berupa masker. Hal ini tidak sesuai dengan rekomendasi APD yang ada pada material safety data sheet. APD pernapasan yang seharusnya disediakan adalah dust respirator yang mampu menyaring partikel berukuran kecil seperti debu halus alumunium sulfat. Hal ini dapat menyebabkan tidak terbuktinya hipotesis bahwa ketersediaan memiliki hubungan signifikan dengan kepatuhan.

Berdasarkan observasi melalui wawancara mendalam, ketersediaan APD di unit produksi alumunium sulfat merupakan tanggung jawab supervisor. Setiap tenaga kerja telah diberikan APD lengkap dan gratis dan jika APD tersebut rusak akan ditukar dengan yang baru. APD juga akan diganti menurut periode tertentu misalnya masker akan diganti setiap tiga bulan sekali. Sekretaris dan supervisor dapat mengajukan rekomendasi spesifikasi pengadaan APD namun pada akhirnya semua jenis pengadaan APD ditentukan oleh pihak manajemen untuk disesuaikan dengan anggaran perusahaan.

Sebaiknya pengadaan APD disesuaikan dengan kebutuhan tenaga kerja agar terlindungi dari bahaya keselamatan dan kesehatan secara adekuat. Pengadaan APD yang ada pada pekerjaan menggunakan mesin grinding mill tidak sesuai dengan kebutuhan tenaga kerja sehingga perlu dilakukan pengadaan alat pelindung pernapasan yang adekuat.

Berdasarkan observasi yang dilakukan tentang alasan tenaga kerja tidak menggunakan APD adalah karena APD yang disediakan mengganggu kenyamanan tenaga kerja ketika bekerja. Meskipun tenaga kerja menyatakan merasa nyaman menggunakan APD pada kuesioner yang diberikan kemudian dicocokkan dengan checklist kepatuhan, ternyata tenaga kerja tersebut tidak patuh menggunakan APD. Ketidaksesuaian antara kuesioner dan checklist kepatuhan tersebut menjadi penyebab tidak adanya hubungan yang signifikan antara ketersediaan APD dengan kepatuhan menggunakan APD. 


\section{Hubungan Sikap terhadap Kebijakan tentang APD dengan Kepatuhan Menggunakan APD}

Kebijakan yang mengatur tenaga kerja untuk menggunakan APD harus menyatakan secara jelas bahwa APD sangat dibutuhkan oleh tenaga kerja untuk melindungi dirinya dan wajib dipatuhi. Kebijakan ini juga harus secara tertulis. Menurut Notoatmodjo (2005), kebijakan merupakan faktor pendorong atau memperkuat untuk terjadinya suatu perilaku. Faktor tersebut meliputi undang-undang, peraturan, pengawasan dan sebagainya. Geller (2001) menyatakan bahwa kebijakan merupakan salah satu faktor dalam komponen environment yang memengaruhi perilaku kepatuhan menggunakan APD pada safety triad.

Tabel 1 menunjukkan bahwa hasil penelitian yang dilakukan di unit produksi alumunium sulfat PT. Liku Telaga dapat membuktikan teori bahwa ada hubungan yang signifikan antara adanya kebijakan dengan kepatuhan menggunakan APD meskipun memiliki kuat hubungan yang rendah. Kuat hubungan yang rendah ini mungkin karena sikap baik maupun kurang terkait kebijakan yang mengatur APD tidak cukup kuat membuat tenaga kerja patuh menggunakan APD.

Hasil penelitian lain yang dilakukan oleh Rengganis (2012) bertolak belakang dengan hasil penelitian di unit produksi alumunium sulfat PT. Liku Telaga. Hasil penelitian Rengganis (2012) menyatakan bahwa tidak ada hubungan yang signifikan antara peraturan dengan perilaku menggunakan APD maupun pengawasan dengan perilaku menggunakan APD. Hasil penelitian yang dilakukan oleh Kurniawan (2009) menyatakan bahwa pemasangan rambu $\mathrm{K} 3$ tidak memiliki hubungan yang signifikan dengan kepatuhan menggunakan APD. Penelitian yang dilakukan oleh Rengganis (2012) dan Kurniawan (2009) tidak dapat membuktikan bahwa kebijakan memiliki hubungan yang signifikan dengan penggunaan APD.

Kebijakan perusahaan yang ada tentang APD secara tertulis menyebutkan bahwa tenaga kerja harus menggunakan APD yang telah diberikan secara gratis. Setiap dinding sebelum pintu masuk unit produksi juga telah terpasang matriks APD yang memandu tenaga kerja menggunakan APD yang wajib digunakan di area unit produksi tersebut. Khusus pekerjaan tertentu seperti pada pekerjaan yang berhubungan dengan asam kuat, supervisor telah memberikan peraturan tentang APD tambahan yang wajib digunakan. Tenaga kerja yang melanggar dengan tidak patuh menggunakan APD akan mendapatkan sanksi berupa teguran, surat peringatan, skorsing dan pemutusan hubungan kerja. Berdasarkan hasil wawancara mendalam dengan sekretaris $\mathrm{P} 2 \mathrm{~K} 3$, tenaga kerja yang melanggar tidak patuh menggunakan APD seringkali mendapatkan sanksi maksimal berupa surat peringatan pertama.

Tenaga kerja memiliki sikap positif terhadap adanya kebijakan yang mengatur penggunaan APD di perusahaan khususnya di unit produksi alumunium sulfat. Berdasarkan analisis data, hubungan antara kebijakan tentang APD dengan kepatuhan tenaga kerja menggunakan APD. Hal ini berarti sikap positif tenaga kerja terhadap adanya kebijakan yang mengatur penggunaan APD merupakan salah satu faktor yang memiliki hubungan dengan kepatuhan tenaga kerja menggunakan APD.

Meskipun kebijakan memiliki hubungan yang rendah, namun hal ini dapat menjadi pertimbangan bahwa dengan menerapkan kebijakan yang tegas akan membuat tenaga kerja lebih patuh menggunakan APD. Kebijakan yang lebih tegas dapat dilakukan dengan memberikan sanksi tanpa toleransi jika tenaga kerja tidak patuh menggunakan APD berulang kali. Tenaga kerja tidak diberikan toleransi untuk memasuki tempat kerja di unit produksi alumunium sulfat hingga tenaga kerja menggunakan APD dengan benar dan lengkap sesuai peraturan.

Kebijakan juga harus menyatakan bahwa tenaga kerja yang selalu patuh menggunakan APD akan diberikan penghargaan. Perusahaan ini telah memberikan penghargaan berupa pulsa kepada tenaga kerja yang selalu patuh menggunakan APD dan diumumkan melalui buletin perusahaan. Sanksi dan penghargaan yang diberikan perusahaan sebagai bentuk feedback perilaku kepatuhan tenaga kerja harus memiliki makna. Penerapan feedback berupa sanksi dan penghargaan yang bermakna akan membuat tenaga kerja patuh menggunakan APD.

Kebijakan merupakan faktor yang memiliki hubungan dengan kepatuhan tenaga kerja dalam menggunakan APD sehingga manajer dapat memanfaatkan dengan mendesain kebijakan untuk membuat semua tenaga kerja patuh pada peraturan penggunaan APD. Hasil penelitian ini mungkin dapat menjadikan masukan pada pihak manajemen untuk memperbaiki kebijakan yang ada di perusahaan agar tenaga kerja lebih patuh menggunakan APD. Saat ini kebijakan yang ada di perusahaan antara lain adalah matriks APD, perintah wajib menggunakan APD yang tertulis pada perjanjian kerja bersama dan standar operasional prosedur tentang pemeliharaan 
APD. Pihak manajemen mungkin bisa mengubah budaya kepatuhan menggunakan APD menjadi lebih baik lagi melalui perbaikan penerapan kebijakan agar semua tenaga kerja patuh menggunakan APD meskipun tanpa diawasi.

Menurut Bisen dan Priya (2005), dukungan tenaga kerja dan pelatihan merupakan elemen yang paling penting untuk menciptakan budaya pada suatu perusahaan. Oleh karena itu untuk membentuk budaya kepatuhan menggunakan APD, perusahaan perlu melibatkan dukungan tenaga kerja dan melaksanakan pelatihan yang sesuai dengan kebutuhan. Dukungan tenaga kerja terhadap kebijakan APD sangat penting karena tenaga kerja adalah pelaku utama dalam perilaku kepatuhan menggunakan APD.

Menurut Leka dan Houdmont (2010), budaya perusahaan sangat dipengaruhi oleh tipe kepemimpinan yang dimiliki oleh pihak manajerial. Berdasarkan teori kepemimpinan tersebut, dapat disimpulkan bahwa tipe kepemimpinan pihak manajerial dalam menyusun kebijakan tentang APD sangat memengaruhi budaya perusahaan tentang APD. Menurut Bisen dan Priya (2010) jika perilaku berubah maka budaya akan berubah. Budaya kepatuhan menggunakan APD akan lebih baik jika tenaga kerja mengubah perilaku tidak patuh menjadi patuh menggunakan APD. Jika tenaga kerja berperilaku patuh menggunakan APD maka akan tercipta budaya kepatuhan menggunakan APD.

Perbaikan kebijakan yang tidak diimbangi dengan perbaikan komitmen pimpinan tidak akan cukup menciptakan perilaku kepatuhan tenaga kerja menggunakan APD. Komitmen pimpinan tersebut harus dipelihara untuk menerapkan kebijakan K3 yang dibuat oleh perusahaan. Komitmen tidak cukup dengan bukti tertulis berupa tanda tangan seluruh tenaga kerja dan pimpinan perusahaan namun harus dibuktikan secara nyata melalui tindakan. Komitmen K3 harus muncul pada semua elemen yang ada di perusahaan mulai dari pembuatan kebijakan, penganggaran pengadaan APD, hingga penerapan untuk menggunakan APD ketika berada di tempat kerja. Tindakan nyata yang dapat dilakukan oleh pimpinan perusahaan termasuk supervisor harus memberikan contoh yang baik kepada tenaga kerja dengan menggunakan APD lengkap dan benar di tempat kerja.

Perusahaan juga perlu mempertimbangkan beberapa hal dalam membuat kebijakan tentang APD diantaranya kesesuaian, standar, kenyamanan, sosialisasi dan evaluasi. Perusahaan harus menyediakan APD yang sesuai dengan jenis risiko bahaya yang ada di lingkungan kerja untuk melindungi tenaga kerja dari risiko kecelakaan dan penyakit akibat kerja. APD yang disediakan harus memenuhi standar yang telah ditetapkan dan nyaman digunakan oleh tenaga kerja sehingga tidak mengganggu proses pekerjaan. Penyediaan APD juga harus disosialisasikan salah satunya dengan mengadakan pelatihan khusus tentang APD. Perusahaan juga harus terus mengevaluasi kebijakan APD yang telah diterapkan secara berkala.

\section{SIMPULAN}

Karakteristik tenaga kerja menunjukkan bahwa sebagian besar tenaga kerja di unit produksi alumunium sulfat PT. Liku Telaga tergolong berumur muda, belum lama bekerja dan memiliki pendidikan yang tinggi. Komponen person menunjukkan bahwa sebagian besar tenaga kerja di unit produksi alumunium sulfat memiliki pengetahuan yang baik tentang APD, motivasi baik untuk menggunakan APD dan berkepribadian tipe B. Komponen behavior menunjukkan bahwa sebagian besar tenaga kerja unit produksi alumunium sulfat PT. Liku Telaga pernah mendapatkan pelatihan menggunakan APD dan memiliki komunikasi yang baik.

Komponen environment menunjukkan bahwa sebagian besar ketersediaan APD di unit produksi alumunium sulfat PT. Liku Telaga yang disediakan perusahaan dalam kondisi lengkap dan tidak rusak dan sebagian besar tenaga kerja di unit produksi alumunium sulfat PT. Liku Telaga memiliki sikap yang tergolong baik terhadap kebijakan tentang APD di perusahaan. Kepatuhan menggunakan APD menunjukkan bahwa sebagian besar tenaga kerja di unit produksi alumunium sulfat PT. Liku Telaga patuh menggunakan APD namun masih ditemukan tenaga kerja yang tidak patuh menggunakan APD. Hanya faktor pendidikan dan kebijakan tentang APD yang memiliki hubungan signifikan dengan kepatuhan menggunakan APD dari seluruh faktor yang diteliti yaitu faktor umur, masa kerja, pengetahuan, motivasi, kepribadian, pelatihan tentang APD, komunikasi, dan pelatihan menggunakan APD. Pendidikan memiliki kuat hubungan yang rendah $(0,336)$ dengan kepatuhan menggunakan APD. Sikap terhadap kebijakan memiliki kuat hubungan yang rendah $(0,233)$ dengan kepatuhan menggunakan APD. 


\section{DAFTAR PUSTAKA}

Ahyar, M. 2001. Hubungan Karakteristik Tenaga Kerja terhadap Pemakaian Alat Pelindung Mulut dan Hidung (Masker). Skripsi. Surabaya: FKM Universitas Airlangga.

Atmodiwirio, Soebagio. 2002. Manajemen Pelatihan. Jakarta: PT Ardadizya Jaya.

Azis, Hamdani. 2010. Hubungan antara Karakteristik dan Tipe Kepribadian Pekerja dengan Tingkat Kepatuhan Penggunaan Alat Pelindung Diri. Skripsi. Surabaya: FKM Universitas Airlangga.

Bisen, Vikram dan Priya. 2010. Industrial Psychology. New Delhi: New Age International Publishers.

Budiono, Sugeng. 2003. Bunga Rampai Hiperkes dan Kecelakaan Kerja. Semarang: Universitas Diponegoro.

Geller, E. Scott. 2001. The Psychology of Safety Handbook. New York: Lewis Publishers.

Haqi, Dani Nasirul. 2013. Analisis Penyebab Unsafe Action dengan Pendekatan Human Factors and Classification System (HFACS). Tesis. Surabaya: FKM Universitas Airlangga.

Hastanti, Rulia. 2004. Faktor yang Berhubungan dengan Pemakaian APD pada Pekerja Konstruksi Bangunan. Skripsi. Surabaya: FKM Universitas Airlangga.

Humau, Dina C. 2012. Beberapa Faktor yang Behubungan dengan Kepatuhan Penggunaan Alat Pelindung Diri APD pada Pekerja Bagian Ring Frame PT. Lotus Indah Textile Industries di Surabaya. Skripsi. Surabaya: FKM Universitas Airlangga.

Jannah, Noer. 2009. Beberapa Faktor yang Berhubungan dengan Pemakaian APD pada Pekerja Laboratorium Patologi Klinik RSUD Sidoarjo. Skripsi. Surabaya: FKM Universitas Airlangga.

Kurniawan. Dedi. 2009. Hubungan Rambu-Rambu K3 dengan Kepatuhan Pemakaian APD (Studi di bagian Asam Sulfat Pabrik III PT. Petrokimia Gresik). Skripsi. Surabaya: FKM Universitas Airlangga.

Leka, Stavroula dan Houdmont, J. 2010. Occupational Health Psychology. Pondicherry: SPi Publisher Service.
McSween, Terry E. 2003. The Values Based Safety Process: Improving Your Safety Culture with Behavior Based Safety. $2^{\text {nd }}$ Edition. New Jersey: John Wiley \& Sons Inc.

Notoatmodjo, S. 2002. Metode Penelitian Kesehatan. Jakarta: Rineka Cipta.

Notoatmodjo, S. 2003. Pendidikan dan Perilaku Kesehatan. Jakarta: Rineka Cipta.

Notoatmodjo, S. 2005. Promosi Kesehatan: Teori dan Aplikasi. Jakarta: Rineka Cipta.

Notoatmodjo, S. 2012. Pendidikan dan Perilaku Kesehatan. Jakarta: Rineka Cipta.

Ramli, Soehatman. 2009. Sistem Manajemen Keselamatan dan Kesehatan Kerja OHSAS 18001. Jakarta: Dian Rakyat.

Reason. 2007. Managing the Risk of Organizational Accidents. Ashgade: Publishing Ltd. Aldershot Hants.

Rengganis, Fitriana. 2012. Faktor yang Memengaruhi Perilaku Tenaga Kerja Percetakan terhadap Penggunaan APD di Bagian Produksi PT. Antar Surya Jaya Surabaya. Skripsi. Surabaya: FKM Universitas Airlangga.

Retnani, D. 2013. Analisis Pengaruh Activator an Consequence terhadap Safe Behavior pada Tenaga Kerja di PT. Pupuk Kalimantan Timur Tahun 2013. Skripsi. Surabaya: FKM Universitas Airlangga.

Sari, Citra Ratna. 2012. Hubungan Karakteristik Tenaga Kerja dengan Kecelakaan Kerja. Skripsi. Surabaya: FKM Universitas Airlangga.

Wibowo, Arianto. 2012. Faktor-faktor yang Berhubungan dengan Perilaku Penggunaan Alat Pelindung Diri di Areal Pertambangan PT. Antam Tbk Unit Bisnis Pertambangan Emas Pongkor Kabupaten Bogor. Skripsi. Jakarta: FKM Universitas Islam Negeri Syarif Hidayatullah.

Yuwono, I. et al. 2005. Psikologi Industri dan Organisasi. Surabaya: FPsi Universitas Airlangga.

Zaendar, Aldo. 2009. Gambaran Aspek Perilaku Metode ABC (Antecedent-BehaviorConsequences) pada Pekerja di Divisi Steel Tower PT. Bukaka Teknik Utama, Tbk. Skripsi. Jakarta: FKM Universitas Indonesia. 